\title{
A meta-analysis on in situ ruminal degradability of grains and meals for energy concentrate feeds
}

\author{
Marcos Busanello1, João Pedro Velho', *, Antônio Augusto Cortiana Tambara ${ }^{3}$, \\ Ione Maria Pereira Haygert-Velho², Dileta Regina Moro Alessio ${ }^{4}$, André Thaler Neto 5
}

\begin{abstract}
${ }^{1}$ Animal Science and Pastures, University of São Paulo - - College of Agriculture "Luiz de Queiroz" (ESALQ), Piracicaba, SP, Brazil, ${ }^{2}$ Department of Animal Science and Biological Sciences, Federal University of Santa Maria (UFSM) - Campus Palmeira das Missões. Palmeira das Missões, RS, Brazil, ${ }^{3} F e d e r a l ~ I n s t i t u t e ~ F a r r o u p i l h a, ~ C a m p u s ~ S a ̃ o ~ V i c e n t e ~ d o ~ S u l, ~ S a ̃ o ~ V i c e n t e ~ d o ~ S u l, ~ R S, ~ B r a z i l, ~{ }^{4}$ Animal Science, Uniersity of the State of Santa Catarina (UDESC), Lages, SC, Brazil, ${ }^{5}$ Department of Animal and Food Production, University of the State of Santa Catarina (UDESC), Lages, SC, Brazil
\end{abstract}

\section{A B S T R A C T}

\begin{abstract}
One factor that may interfere with rumen fermentation is the physical form of feed, because of the colonization by bacteria during processing. Here, we aimed to perform a meta-analysis and evaluate the in situ ruminal degradability of energy feeds with distinct physical forms (grain vs. meal). We created a database, comprising 39 treatments from 12 studies conducted in Brazil, and focused on parameters for the potential and effective degradability of dry matter (DM) and crude protein (CP) of energy feeds. The results showed that there was no difference $(P>0.05)$ in any of the degradability parameters of DM and CP between the grain and meal. However, the readily soluble fraction of DM in the grain showed a higher degradability trend $(P=0.0888)$. Overall, it was concluded that the processing of energy feeds does not modify the degradability parameters of DM and CP, and that further studies need to be conducted in Brazil to evaluate the in situ ruminal degradability of starch.
\end{abstract}

Keywords: Grain; Meal; Metabolism; Processing; Ruminants

\section{INTRODUCTION}

Energy is one of the main factors that directly affect the animal production systems. In ruminants, carbohydrates and protein are important nutrients used as substrates for microbial synthesis. Therefore, the formulation of diets for ruminants aims to enhance the production of microbial protein, the nutrient amount absorbed in the small intestine, and consequently, animal performance (Seo et al., 2010). However, ruminal metabolism is influenced by several factors such supply of carbohydrates and nitrogen for different pools of bacterial microbiota. Therefore, one factor that can interfere with the rumen fermentation of feeds is their physical form. Grains and other diet ingredients are processed to alter their physical structure and/or chemical composition (Nasri et al., 2008). Processing of energy ingredients aims to increase the availability of starch in the rumen, especially by weakening the bonds between protein and starch granules (Stevnebø et al., 2006). Processing of grain modifies the structural characteristics of starch and its interaction with other endosperm components by altering the digestibility (Svihus et al., 2005). Degradability of diet ingredients increases when the starch becomes more accessible to microorganisms (Tester et al., 2006). As a result, the meals last longer, with increased voluntary consumption and production of microbial protein, resulting in increased animal response (Pazdiora et al., 2011; Moharrery et al., 2014).

Various studies have been conducted in Brazil, focusing on in situ ruminal degradability. We used combined data from previous studies to perform a meta-analysis that would allow us to develop further correct estimates and increase the statistical power in a relatively inexpensive way (Hooijmans et al., 2014). Our objective was to assess whether ruminal

\footnotetext{
*Corresponding author:

João Pedro Velho, Department of Animal Science and Biological Sciences, Federal University of Santa Maria (UFSM) - Campus Palmeira das Missões. Palmeira das Missões, RS, Brazil, Avenida Independência 3751, 98300-000, Palmeira das Missões, RS, Brazil.

E-mail: velhojp@ufsm.br

Received: 21 August 2017; Accepted: 11 February 2018
} 
degradability in situ is different for energy concentrated feeds with different physical forms.

\section{MATERIAL AND METHODS}

We performed a search in scientific sites of public dominium for studies on in situ ruminal degradability conducted in Brazil and published between January 1998 and December 2013. We found 12 studies, including Beran et al. (2005), Fortaleza et al. (2009), Garcia et al. (2003), Goes et al. (2004), Goes et al. (2011), Marcondes et al. (2009), Martins et al. (1999), Mizubuti et al. (2007), Oliveira et al. (2003), Silva et al. (1999), Silveira et al. (2002), and Zeoula et al. (1999), that studied in situ ruminal degradability of grains of oats (Avena sativa), cotton (Gossypium birsutum), sunflower (Helianthus annuus), corn (Zea mays), sorghum (Sorghum bicolor), wheat (Triticum aestivum), and triticale (Triticosecale), and also in situ ruminal degradability of meals of cotton, rice (Oryza sativa), maize germ, sunflower, and wheat. Studies cited availed degradability for some of these ingredients where degradability for all these ingredients was not necessarily studied in all the studies cited. Data from 39 treatments found in the 12 studies were tabulated in Excel (Microsoft Corp., Redmond, WA, USA), and the assumptions were set as described by Lovatto et al. (2007).

In all studies, the potential degradability was estimated as described by Ørskov and McDonald (1979):

$\mathrm{p}=\mathrm{a}+\mathrm{b}\left(1-\mathrm{e}^{-\mathrm{ct}}\right)$,

where $\mathrm{p}$ is the potential degradability; $\mathrm{A}$ is the watersoluble fraction; $\mathrm{B}$ is the insoluble fraction, but potentially degradable; and $\mathrm{C}$ is the degradation rate for ' $\mathrm{b}$ '.

The effective degradability of dry matter (EDDM) and crude protein (EDCP) was estimated as follows:

$\mathrm{EDDM} / \mathrm{EDCP}=\mathrm{a}+[(\mathrm{b} * \mathrm{c}) /(\mathrm{c}+\mathrm{k})]$, where $\mathrm{k}$ is the particle passage rate in the rumen. In general, the recommended particle passage rates by the Agricultural and Food Research Council (AFRC, 1993) are 2\% per $\mathrm{h}$ for animals with energy consumption lower than the maintenance; $5 \%$ per $\mathrm{h}$ for calves and cows producing less than $15 \mathrm{~kg}$ of milk per d, and beef cattle and sheep with energy consumption less than twice the maintenance; and $8 \%$ per h for dairy cows producing over $15 \mathrm{~kg}$ of milk per $d$ or with energy consumption more than twice the maintenance.

Feeds were classified based on protein concentration as suggested by the Ministério da Agricultura, Pecuária e Abastecimento (MAPA, 2013). Analysis of variance was performed on SAS ${ }^{\circledR}$ (SAS Institute, 2002) using the mixed model and considering each study as a random variable. Differences were considered significant at $P<0.05$ and trend at $P<0.10$.

\section{RESULTS AND DISCUSSION}

Based on the rates of DM (Table 1), the feeds were stored under appropriate conditions in all the studies. The rate of DM is important, since it protects feed nutrients from digestion and from being metabolized by microorganisms during storage (Santos et al., 2012).

No differences were found between grain versus meal for DM ( $p=0.1807)$, water-soluble fraction of DM $(\mathrm{p}=0.0888)$, potential degradable fraction of $\mathrm{DM}$ $(p=0.9707)$, degradation rate of DM ( $p=0.4657)$, effective degradability at $2 \%$ per h of DM $(p=0.6760)$, effective degradability at $5 \%$ per h of DM $(p=0.8387)$, effective degradability at $8 \%$ per h of DM $(p=0.8373)$ (Table 1$)$. Moreover, no differences were found between grain versus meal for $\mathrm{PB}(\mathrm{p}=0.3501)$, water-soluble fraction of $\mathrm{PB}(\mathrm{p}=0.1978)$, potential degradable fraction of $\mathrm{PB}$ $(p=0.8263)$, degradation rate of $\mathrm{PB}(\mathrm{p}=0.8679)$, effective degradability at $2 \%$ per h of $\mathrm{PB}(\mathrm{p}=0.6878)$, effective degradability at $5 \%$ per h of $\mathrm{PB}(\mathrm{p}=0.3961)$, effective degradability at $8 \%$ per h of $\mathrm{PB}(\mathrm{p}=0.3412)$ (Table 2$)$.

The lack of differences could be attributed to the processing methods, such as fine grinding, coarse grinding,

Table 1: Adjusted mean of dry matter (DM), water-soluble fraction (a) of DM, potentially degradable fraction (b) of DM, degradation rate (c) of DM, and effective degradability at $2 \%, 5 \%$, and $8 \%$ DM per $h$ in grain and meal

\begin{tabular}{|c|c|c|c|c|c|}
\hline \multirow[t]{2}{*}{ Parameter } & \multirow[t]{2}{*}{$\mathbf{N}$} & \multicolumn{2}{|c|}{ Physical Form } & \multirow[t]{2}{*}{ Standard error } & \multirow[t]{2}{*}{ Probability } \\
\hline & & Grain & Meal & & \\
\hline Dry matter (\% of natural matter) & 32 & 92.01 & 89.54 & 1.80 & 0.1807 \\
\hline Water-soluble fraction $(a)^{*}$ & 27 & 16.25 & 14.67 & 6.82 & 0.0888 \\
\hline Potentially degradable fraction $(b)^{*}$ & 29 & 61.87 & 62.20 & 8.87 & 0.9707 \\
\hline Degradation rate $(\mathrm{c})^{\star}$ & 27 & 7.58 & 6.35 & 1.67 & 0.4657 \\
\hline Effective degradability at $2 \%$ per $\mathrm{h}^{*} \dagger$ & 19 & 81.30 & 75.87 & 12.78 & 0.6760 \\
\hline Effective degradability at $5 \%$ per $\mathrm{h}^{\star} \dagger$ & 25 & 61.52 & 65.12 & 6.82 & 0.8387 \\
\hline Effective degradability at $8 \%$ per $\mathrm{h}^{\star} \dagger$ & 23 & 57.54 & 55.80 & 8.39 & 0.8373 \\
\hline
\end{tabular}

*Values determined as described by Ørskov and McDonald (1979); † Values determined at different passage rates as suggested by the agricultural and food research council (1993) 
Table 2: Adjusted mean of crude protein (CP), water-soluble fraction (a) of CP, potentially degradable fraction (b) of CP, degradation rate (c) of $\mathrm{CP}$, and effective degradability at $2 \%, 5 \%$, and $8 \%$ of $\mathrm{CP}$ per $\mathrm{h}$ in grain and meal

\begin{tabular}{|c|c|c|c|c|c|}
\hline \multirow[t]{2}{*}{ Parameter } & \multirow[t]{2}{*}{$\mathrm{N}$} & \multicolumn{2}{|c|}{ Physical Form } & \multirow[t]{2}{*}{ Standard error } & \multirow[t]{2}{*}{ Probability } \\
\hline & & Grain & Meal & & \\
\hline Crude protein ( $\%$ of dry matter) & 30 & 12.78 & 10.98 & 1.90 & 0.3501 \\
\hline Water-soluble fraction $(a)^{*}$ & 27 & 22.23 & 11.79 & 7.90 & 0.1978 \\
\hline Potentially degradable fraction $(b)^{*}$ & 29 & 52.64 & 50.92 & 7.79 & 0.8263 \\
\hline Degradation rate $(\mathrm{c})^{*}$ & 27 & 6.90 & 7.32 & 2.46 & 0.8679 \\
\hline Effective degradability at $2 \%$ per $h^{*} \dagger$ & 19 & 62.68 & 54.64 & 19.04 & 0.6878 \\
\hline Effective degradability at $5 \%$ per $\mathrm{h}^{*} \dagger$ & 25 & 49.02 & 41.19 & 9.07 & 0.3961 \\
\hline Effective degradability at $8 \%$ per $\mathrm{h}^{*} \dagger$ & 23 & 42.73 & 32.47 & 10.55 & 0.3412 \\
\hline
\end{tabular}

*Values determined as described by Ørskov and McDonald (1979); † Values determined at different passage rates as suggested by the agricultural and food research council (1993)

extrusion, and flocculation, used to facilitate microbial action (Vargas Jr. et al., 2008). These methods usually do not change the chemical composition of the feeds, except for oil extraction, peeling, and extrusion that reduce the ether extract and fibre contents in the meal (Cação et al., 2012). Therefore, processing changes the structural links between starch and protein and also the availability of the lipid fraction (Bertipaglia et al., 2008).

Studies indicated that processing could affect starch degradability (Ørskov, 1986; Simas et al., 2008), but our study found that processing on energy concentrated ingredients did not affect the DM and PB degradability. However, other factors also could affect the degradability of the feeds as cultivar (Rossi et al., 2016), feed origin like coproduct or others (Busanello et al., 2016a; Lee et al., 2016), soluble carbohydrate content (Poorkasegaran and Yansari, 2014), neutral detergent fibre (NDF) and acid detergent fibre (ADF) (Busanello et al, 2016b; Lee et al., 2016).

The readily water-soluble fraction of $\mathrm{DM}$ showed a higher degradability trend $(\mathrm{P}=0.0888)$ in the grain than in the meal (Table 1). Processing reduces the water-soluble fractions and interferes with degradability parameters, making the meal more accessible to microbial action, and consequently, modifying the microbial protein production (Shabi et al., 1999; Dhiman et al., 2002; Dehghan-Banadaky et al., 2007; Sveinbjörnsson et al., 2007, Moharrery et al., 2014). However, further research is needed in order to uncover the differences in ruminal degradation between the grain and meal.

Without any significant differences in the ruminal potential and effective degradability of DM and CP between the grain and meal of energy concentrated ingredients, diet formulation depends on animal species and physiological state as well as the availability and cost of the ingredients. Bolzan et al. (2007) evaluated corn grain meal fed to the sheep and concluded that grinding is not necessary, because the liquid nutritional requirements can be met by the addition of concentrated feed in the diet. In primiparous young cows (22-24 months old) that produce approximately $30 \mathrm{~kg}$ of milk d $^{-1}$, the diet needs to optimize the voluntary intake, since the pass rate is between $5 \%$ and $8 \%$ per $\mathrm{h}$ and reduces feed utilization (Linden et al., 2014). Feeds with relatively high degradation rates (fraction c) are those that increase the voluntary intake (Pereira et al., 2003).

Most Brazilian studies on degradability have focused on the evaluation of DM and CP, since the available techniques have a relatively low cost and effort level. However, future studies need to investigate the relationship between starch (cell content) and cellulose, hemicellulose, and pectin (cell wall carbohydrates) by using gravimetric analysis (Hall, 2003).

\section{CONCLUSION}

Feed processing does not change the ruminal degradability of DM and CP of energy concentrated feeds with distinct physical forms. Further studies are needed to evaluate the in situ ruminal degradability of starch in Brazil.

\section{ACKNOWLEDGEMENTS}

This study was supported by the Financiadora de Estudos e Projetos (FINEP) of the Ministério da Ciência e Tecnologia (MCT) through the Public Call MCT/FINEP/CT-INFRACAMPI REGIONAL-01/2010.

\section{AUTHORS' CONTRIBUTIONS}

The subject present in this research was idealized by JPV and MB. Statistical analysis was performed by DRMA. Moreover, all the authors helped with the write of the manuscript and suggestions.

\section{REFERENCES}

AFRC. 1993. Energy and protein requirements of ruminants. $1^{\text {st }}$ ed Agricultural and Food Research Council - CAB International, Wallingford, UK. 
Beran, F. H. B., L. D. F. Silva, E. L. A. Ribeiro, V. S. Castro, R. A. Correa, É. O. Kagueyama and M. A. Rocha. 2005. Degradabilidade ruminal "in situ" da matéria seca, matéria orgânica e proteína bruta de alguns suplementos concentrados usados na alimentação de bovinos. Semin. Ciênc. Agrár. 26: 405-418.

Bertipaglia, L. M. A., G. M. P. Melo, A. Sugohara, W. J. Melo and L. A. Bertipaglia. 2008. Alterações bromatológicas em soja e milho processados por extrusão. R. Bras. Zootec. 37: 2003-2010.

Bolzan, I. T., L. M. B. Sanchez, P. A. Carvalho, J. P. Velho, L. D. Lima, J. Morais and R. L. Jr. Cadorin. 2007. Consumo e digestibilidade em ovinos alimentados com dietas contendo grão de milho moído, inteiro ou tratado com ureia, com três níveis de concentrado. Ciênc. Rural. 37: 229-234.

Busanello, M., J. P. Velho, A. A. C. Tambara, D. R. M. Alessio, I. M.P. Haygert-Velho and A. T. Neto. 2016a. A meta-analysis of in situ degradability of corn grains and non-starch energy sources found in Brazil. Afr. J. Agric. Res. 11: 1902-1907.

Busanello, M., J. P. Velho, A. A. C. Tambara, D. R. M. Alessio, A T. Neto and I. M. P. Haygert-Velho. 2016b. In situ ruminal degradability of soybean meal and alternative protein feeds in Brazil - A metaanalysis. Asian J. Agric. Food Sci. 4: 117-123.

Cação, M. M. F., C. Costa, P. R. L. Meirelles, J. M. B. Ezequiel, R. L. Galati and M. G. B. Silva. 2012. Degradabilidade ruminal da matéria seca de grãos de milho e de sorgo com alto ou baixo conteúdo de tanino processados. Rev. Bras. Saúde Prod. Anim. 13: 516-528.

Dehghan-Banadaky, M., R. Corbett and M. Oba. 2007. Effects of barley grain processing on productivity of cattle. Anim. Feed Sci. Tech. 137: 1-24.

Dhiman, T. R., M. S. Zaman, I. S. Macqueen and R. L. Boman. 2002. Influence of corn processing and frequency of feeding on cow performance. J. Dairy Sci. 85: 217-226.

Fortaleza, A. P. S., L. D. F. Silva, E. L. A. Ribeiro, R. P. Barbero, F. L. Jr. Massaro, A. X. Santos, V. S. Castro and F. A. B. Castro. 2009. Degradabilidade ruminal in situ dos componentes nutritivos de alguns suplementos concentrados usados na alimentação de bovinos. Semin. Ciênc. Agrár. 30: 481-496.

Garcia, J., C. R. Alcalde, C. C. Jobim, M. A. Zambom, J. C. Damasceno and V. C. Santos. 2003. Degradabilidade in situ de alimentos concentrados e do capim Brachiaria decumbens Stapf. em diferentes crescimentos vegetativos. Acta Sci. Anim. Sci. 25: 387-395.

Goes, R. H. T. B., A. B. Mancio, S. C. V. Filho and R. P. Lana. 2004. Degradação ruminal da matéria seca e proteína bruta, de alimentos concentrados utilizados como suplementos para novilhos. Ciênc. Agrotec. 28: 167-173.

Goes, R. H. T. B., K. A. Souza, K. A. G. Nogueira, D. F. Pereira, E. R. Oliveira and K. C. S. Brabes. 2011. Degradabilidade ruminal da matéria seca e proteína bruta, e tempo de colonização microbiana de oleaginosas, utilizadas na alimentação de ovinos. Acta Sci. Anim. Sci. 33: 373-378.

Hall, M. B. 2003. Challenges with nonfiber carbohydrate methods. J. Anim. Sci. 81: 3226-3232.

Hooijmans, C. R., J. Inthout, M. Ritskes-Hoitinga and M. M. Rovers. 2014. Meta-analyses of animal studies: An introduction of a valuable instrument to further improve healthcare. ILAR J. 55: 418-426.

Lee, Y. H., F. Ahmadi, D. Y. Choi and W. S. Kwak. 2016. In situ ruminal degradation characteristics of dry matter and crude protein from dried corn, high-protein corn, and wheat distillers grains. J. Anim. Sci. Technol. 58: 33.

Linden, D. R., E. C. Titgemeyer, K. C. Olson and D. E. Anderson. 2014. Effects of gestation and lactation on forage intake, digestion, and passage rates of primiparous beef heifers and multiparous beef cows. J. Anim. Sci. 92: 2141-2151.

Lovatto, P. A., C. R. Lehnen, I. Andretta, A. D. Carvalho and L. Hauschild. 2007. Meta-análise em pesquisas científicas Enfoque em metodologias. R. Bras. Zootec. 36: 285-294.

MAPA. 2013. Ministério da Agricultura, Pecuária e Abastecimento MAPA, Brasil.

Marcondes, M. I., S. C. V. Filho, E. Detmann, R. F. D. Valadares, L. F. C. Silva and M. A. Fonseca. 2009. Degradação ruminal e digestibilidade intestinal da proteína bruta de alimentos para bovinos. R. Bras. Zootec. 38: 2247-2257.

Martins, A. S., L. M. Zeoula, I. N. Prado, E. N. Martins and V. R. Loyola. 1999. Degradabilidade ruminal in situ da matéria seca e proteína bruta das silagens de milho e sorgo e de alguns alimentos concentrados. R. Bras. Zootec. 28: 1109-1117.

Mizubuti, I. Y., F. B. Moreira, E. L. A. Ribeiro, E. S. Pereira, M. A. Rocha and M. F. Silva Filho. 2007. Degradabilidade in situ da matéria seca e da proteína bruta do farelo de arroz, farelo de trigo, grão de milho e grão de aveia. Acta Sci. Anim. Sci. 29: 187-193.

Moharrery, A., M. Larsen and M. R. Weisbjerg. 2014. Starch digestion in the rumen, small intestine, and hind gut of dairy cows - A meta-analysis. Anim. Feed Sci. Tech. 192: 1-14.

Nasri, M. H. F., J. France, M. D. Mesgaran and E. Kebreab. 2008. Effect of heat processing on ruminal degradability and intestinal disappearance of nitrogen and amino acids in Iranian whole soybean. Livest. Sci. 113: 43-51.

Oliveira, M. V. M., F. M. Jr. Vargas, L. M. B. Sanchez, W. Paris, A. Frizzo, I. P. Haygert, D. Montagner, A. Weber and L. Cerdótes. 2003 (Supl. 2). Degradabilidade ruminal e digestibilidade intestinal de alimentos por intermédio da técnica in situ associada à do saco de náilon móvel. R. Bras. Zootec. 32: 2023-2031.

Ørskov, E. R. and I. McDonald. 1979. The estimation of protein degradability in the rumen from incubation measurements weighted according to rate of passage. J. Agri. Sci. 92: 499-503.

Ørskov, E. R. 1986. Starch digestion and utilization in ruminants. J. Anim. Sci. 63: 1624-1633.

Pazdiora, R. D., I. L. Brondani, M. F. Silveira, M. Z. Arboitte, J. Cattelam and P. C. Paula. 2011. Efeitos da frequência de fornecimento do volumoso e concentrado no comportamento ingestivo de vacas e novilhas em confinamento. R. Bras. Zootec. 40: 2244-2251.

Pereira, E. S., A. M. V. Arruda, I. Y. Mizubuti and L. D. F. Silva. 2003. Consumo voluntário em ruminantes. Semin. Ciênc. Agrár. 24: 191-196.

Poorkasegaran, S. and A. T. Yansari. 2014. Effects of different sources of carbohydrates on intake, digestibility, chewing, and performance of Holstein dairy cows. J. Anim. Sci. Biotechnol. 5: 6.

Rossi, E. S., M. V. Faria, M. C. Mendes, M. Neumann, A. Gabriel and M. V. Del Conte. 2016. Bromatological characteristics and ruminal digestibility of grain corn hybrids with different vitreousness in silage maturity. Acta Sci. Agron. 38: 337-344.

Santos, S. B., M. A. Martins, L. R. D. Faroni and V. R. Jr. Brito. 2012. Perda de matéria seca em grãos de milho armazenados em bolsas herméticas. Rev. Ciênc. Agron. 43: 674-682.

SAS Institute. 2002. SAS/STAT. Guide for Personal Computers. Cary, $1 \mathrm{v}$.

Seo, J. K., M. H. Kim, J. Y. Yang, H. J. Kim, C. H. Lee, K. H. Kim and J. K. Ha. 2010. Effects of synchronization of carbohydrate and protein supply on ruminal fermentation, nitrogen metabolism and microbial protein synthesis in Holstein steers. Asian Austral. J. Anim. 23: 1455-1461. 
Shabi, Z., I. Bruckental, S. Zamwell, H. Tagari and A. Arieli. 1999. Effects of extrusion of grain and feeding frequency on rumen fermentation, nutrient digestibility, and milk yield and composition in dairy cows. J. Dairy Sci. 82: 1252-1260.

Silva, L. D. F., J. M. B. Ezequiel, P. S. Azevedo, J. C. Barbosa, J. W. Cattelan, F. D. Resende, J. R. C. Seixas and F. R. G. Carmo. 1999. Degradabilidade ruminal in situ da matéria seca, matéria orgânica e da proteína bruta de alguns alimentos em novilhos. Semin. Ciênc. Agrár. 20: 25-30.

Silveira, R. N., T. T. Berchielli, D. Freitas, A. K. D. Salman, P. Andrade, A. V. Pires and J. J. R. 2002. Fermentação e degradabilidade ruminal em bovinos alimentados com resíduos de mandioca e cana-de-açúcar ensilados com polpa cítrica peletizada. R. Bras. Zootec. 31: 793-801.

Simas, J. M. C., A. V. Pires, I. Susin, F. A. P. Santos, C. Q. Mendes, R. C. Jr. Oliveira, and J. J. R. Fernandes. 2008. Efeitos de fontes e formas de processamento do amido na utilização de nutrientes e parâmetros ruminais de vacas em lactação. Arq. Bras. Med. Vet. Zootec. 60: 1128-1134.

Stevnebø, A., S. Sahlströmb and B. Svihus. 2006. Starch structure and degree of starch hydrolysis of small and large starch granules from barley varieties with varying amylose content. Anim. Feed Sci. Tech. 130: 23-38.

Sveinbjörnsson, J., M. Murphy and P. Udén. 2007. In vitro evaluation of starch degradation from feeds with or without various heat treatments. Anim. Feed Sci. Tech. 132: 171-185.

Svihus, B., A. K. Uhlen and O. M. Harstad. 2005. Effect of starch granule structure, associated components and processing on nutritive value of cereal starch: A review. Anim. Feed Sci. Tech. 122: 303-320.

Tester, R. F., X. Qi and J. Karkalas. 2006. Hydrolysis of native starches with amylases. Anim. Feed Sci. Tech. 30: 39-54.

Vargas, F. M. Jr., L. M. Sanchez, F. S. Wechsler, W. Bianchini and M. V. M. Oliveira. 2008. Influência do processamento do grão de milho na digestibilidade de rações e no desempenho de bezerros. R. Bras. Zootec. 37: 2056-2062.

Zeoula, L. M., A. S. Martins, I. N. Prado, C. R. Alcalde, A. F. Branco and G. T. Santos. 1999. Solubilidade e degradabilidade ruminal do amido de diferentes alimentos. R. Bras. Zootec. 28: 898-905. 